\title{
A Dilemma between Firm Survivability and Business Ethic in Indonesia
}

\section{ARI KUNCORO}

Universitas Indonesia

arik.lpmfeui@gmail.com

p-ISSN 2477-118X

e-ISSN 2615-7977

\section{A B S T R A C T}

For a private firm the primary concern of stakeholders from management, employees and shareholders is sustainability. Not so much about ethics, particularly if survival is at stake. Business environment however is not always friendly. Uncertainty could come from government regulations. Many regulations are created to correct for negative externalities from private firm operation. Facing the possibility of business stoppage, many firms would have no choice but to pay grease money to speed up the process.

One example of regulation that may have adverse impact on manufacturing is import restriction or import licensing on vital imported inputs. In order to produce high quality product firms often have import critical inputs simply because the domestic industry is unable to meet the quality or simply it does not exist. Particularly so is an export-oriented firm that has to compete in the global market.

Interestingly, import bans, import restrictions and other types of quantitative restrictions may not be binding. The execution 
of prohibitive regulations is mainly in the hand of lower level bureaucrats. With weak supervision from the upper echelon, private firms with their survivability at stake may have to forego "ethics" by bribing lower level bureaucrats in order to obtain vital inputs.

Using the annual survey of Indonesia manufacturing we examine the behaviour of manufacturing in the post-commodity boom era after 2012 when the country is becoming more protectionist. The initial hypothesis suggests that exporting firms use imported inputs proportionally higher than non-exporters. As a result, when the government restricted import in the post commodity boom era, the proportion of bribe and representation expense is higher than their non-exporting counterparts. This behaviour is also observed when instead, FDI versus non FDI firms are compared. Overall there is no increase on the firm export orientation

Keywords: development economics, governance, taxation

\section{A B S T R A K}

Bagi suatu unit usaha tujuan utama dari para pemegang saham, mamajemen dan karyawan adalah keberlanjutan usaha. Walaupun demikian lingkungan usaha tidak selalu ramah. Ketidakpastian dapat berasal dari regulasi yang berubah-ubah. Regulasi dirancang untuk mengoreksi eksternalitas negatif dari beroperasinya unitunit usaha di sector swasta. Tapi regulasi seriang kali dibuat untuk menciptakan beban yang tidak perlu untuk dimanfaatkan oleh birokrat yang korup untuk menarik rente. Pengusaha seringkali membayar suap untuk memperlancar usahanya.

Istilah uang suap mempunyai banyak arti tetapi definisi yang umum yang sering dipakai dalam ilmu ekonomi adalah penyalahgunaan jabatan publik untuk memungut suap dari masyarakat. Suap akan merusak efisiensi karena sifatnya yang tidak transparan. Bagi sektor swasta membayar suap mirip dengan perjapakan karena mengambil uang dari kegiatan usaha. Akan tetapi suap adalah kegiatan illegal. Kebutuhan untuk menghindari deteksi dan penindakan hukum membuat suap tidak efisien seperti perpajakan. Suap adalah kontrak yang tidak dapat diajukan ke pengadilan jika terjadi perselisihan. Hal ini merupakan peluang bagi penerima suap untuk ingkar janji dan atau meminta suap lebih tinggi dari pemberi suap. 
Salah satu contoh regulasi yang mempunyai dampak negatif terhadap sektor manufaktur adalah pembatasan atau lisensi impor dari bahan baku dan barang setengah jadi untuk masukan (input) bagi industri hilir. Untuk memproduksi barang akhir yang berkualitas tinggi perusahaan terutama eksportir sering kali harus mengimpor barang input industri dari luar negeri karena barang tersebut belum dapat diproduksi di dalam negeri atau kualitasnya belum memadai. Yang menarik pembatasan impor tersebut seringkali tidak mengikat karena pelaksanaannya ada di lapangan yang membuka peluang bagi oknum birokrat meminta suap untuk melonggarkan larangan. Perusahaan seringkali mengalami dilemma etik antara membayar suap untuk kelangsungan perusahaan atau tidak membayarnya yang berarti usahanya dapat bangkrut.

Dengan mengunakan data mikro Survei Industri penulis mencoba menangkap tingkah laku ini dengan membedakan antara periode dimana pembatasan impor relatif ringan (zaman bonanza komoditas 2005-2012) dengan jaman paska bonanza komoditas (2012-2015). Analisis juga diperpanjang hingga era sebelum Krisis Moneter 1998.

Kata kunci: ekonomi pembangunan, pemerintahan, perpajakan

\section{A. INTRODUCTION}

In the 1998 economic crisis, the public perception on corruption in Indonesia was changed almost overnight in 1998. After almost 30 years of recognizing corruption as economically begin or even beneficial to the economic development, the public opinion was now shifting toward a concern that corruption hampered economic development (MacIntyre [2001]). What has been happening with small corruption at the firm level is however relatively unknown. For a private firm the primary concern of stakeholders from management, employees and shareholders is sustainability. Business environment however is not always friendly. Uncertainty could come from changes in government regulations. Facing the possibility of business stoppage, business ethics and illegality may have little meaning, many firms would have no choice but to pay grease money to speed up the process provided that the amount is "small."

The term "grease money" has many meanings, but economists use it as the misuse of public office to extort people or private sector 
grease moneys public officials to gain favour (Bardhan [1997]). Grease money works against economic efficiency mainly because it is secretive. From the point of view of private companies, paying is like taxation, since both take money from private business, but bribing is illegal. The need to avoid detection and punishment makes grease money less efficient than taxation. A grease money is a contract that cannot be enforced in court. This creates the opportunity for the grease money-taker to renege - or to demand a higher grease money from the buyer.

One example of regulation that may have adverse impact on manufacturing is import restriction or import licensing on vital imported inputs. In order to produce high quality product firms often have import critical inputs simply because the domestic industry is unable to meet the quality or simply it does not exist. Particularly so is an export oriented firm that has to compete in the global market.

Interestingly, import bans, import restrictions and other types of quantitative restrictions may not be binding. The execution of prohibitive regulations is mainly in the hand of lower level bureaucrats. With weak supervision from the upper echelon, private firms with their survivability at stake may have to forego "ethics" by bribing lower level bureaucrats in order to obtain vital inputs.

Import restrictions may happen when a country in a difficult situation for example when it is facing a huge current account deficit i.e. its exports fall below imports for an extended duration. For instruments, a country may use tariff or non-tariff (quantitative) measures or both. The use of tariff as an instrument to limit imports have fallen dramatically due to the role of World Trade Organization (WTO), multilateral and bilateral agreements. But in adherence to the WTO regulations, it has been replaced by more subtle form of non-tariff measures (NTM) ranging from health to environmental concerns. In the Indonesian case, the deterioration of the current account balance in the post-commodity boom from 2012 onward had instituted many non-tariff barriers. The usual argument is to protect the domestic from unfair external competition. This practice encompasses two administrations: Susilo Bambang Yudhoyono (SBY) and Jokowi (JKW).

Using the annual survey of Indonesia manufacturing we examine the behaviour of manufacturing in the post-commodity boom era after 2012 when the country is becoming more protectionist. This behaviour will be compared to the commodity boom era from 2006 to 
2012. The analysis will also be extended to pre-Asian Financial Crisis (AFC) before the year of 2000. Two key variables will be examined. First is the contribution of firm to gift, charity etc. as a proxy for "grease moneys" as a percentage of total costs. The second variable is "representation: expenses which captures how much a firm use resources to entertain bureaucrats. In a strict way, this is not a grease money like in the traditional sense but it may serve the same purpose. Grease money and representation expenses may be complementary or substitution in practice.

The initial hypothesis suggests that exporting firms use imported inputs proportionally higher than non-exporters. As a result, when the government restricted import in the post commodity boom era, the proportion of grease money and representation expense is higher than their non-exporting counterparts. This behaviour is also observed when instead, FDI versus non FDI firms are compared.

Conceptual Framework

The literature remains ambiguous predictions about the relationship between corruption and economic transaction. There are two major dominant views. In one view for example Huntington (1968) asserted that grease moneys are needed in the world characterised by full of excessive taxes and regulations would remain excessive without grease moneyry, so grease moneyry had in effect acted like deregulation. This view is called as the efficient grease hypothesis, which argues that corruption could expedite economic transaction and thus would increase economic growth since it functions as grease money, which enables firms to walk away from bureaucratic red tape. Lui (1985) was in favour this view showed that in a queuing fashion, corruption could be growth enhancing. In this setting, the size variation of grease moneys by different firms may capture their various opportunity costs with respect to the respective bureaucratic delays. Therefore, buying lower red tapes could increase efficiency. The critical assumption of the efficient grease model is that the red tape and regulatory burden can be regarded as exogenous independent of the incentive for officials to take grease moneys.

In contrast, the second view rejects the notion that corruption could be efficiency enhancing, for example Rose-Ackerman (1974 and 1978), Shleifer and Vishny (1993 and 1994), Bliss and Di Tella (1997) and Kaufman and Wei (1999). The opposite view suggested that because the bureaucrats have discretionary power with given regulation, 
regulatory burden may endogenously set by corrupt officials such that they customize the nature and amount of harassment on firms to extract maximum grease money possible. In this model firms that pay more grease moneys could still face higher, not lower effective red tape. Consequently, corruption could lower economic efficiency instead of improving it.

\section{Data}

The primary concern in the study of grease money is how to get reliable data. Even with a carefully designed question set, it would be unrealistic to expect all respondent to fill out or to answer all items on such questions. Given the secretive nature of corruption it will be difficult for someone conducting a survey to obtain honest answer on items related to such activities. The proxy for grease moneys is obtained from the annual manufacturing from 1980 to 2017. It covers all industries in the large and medium manufacturing and the series are long. Potentially we can construct a long panel data to study the dynamic of grease moneys.

\section{Indonesian Manufacturing Sector in Policy Context}

Firms would thrive if the business environment is conducive are supportive. Some risks can be anticipated and taken care of, firms however will not operate if uncertainties are deemed too high. In this case the role of government is important to maintain law and order, providing basic infrastructures, and regulation of firms and transactions to address information asymmetries, externalities and market power.

The most crucial regulations pertaining to private firms have been laws governing investment in Indonesia which were designed to minimize uncertainties. The investment law in Indonesia commenced in 1967 with the introduction of Law number 1 on foreign direct investment, to be followed later in 1968 by Law number 6 on domestic investment. With these Laws, investors were entitled to tax and import duty holidays facility to import machinery or equipment unavailable domestically, facility to import essential raw and supporting materials not available domestically. Though this was a huge first step, in reality various deregulations were still very much in place intended to protect state own enterprises (SOE). Private firms both domestic and foreign did not have much room to do business as most sectors were still in the red zone list. 


\section{Reforms in mid 1980 s}

The watershed moment came in mid 1980 s when in a response of the fall of revenues from oil the mainstay of Indonesian export and government revenues, the government began to liberalise the economy. Major reforms were aimed at reducing Indonesia's excessive dependence on oil as a revenue source. These reform programs were designed to sustain a momentum of economic development over the medium- to long-term. Pro market elements were the main ingredient of these reforms, designed to reduce high level of regulations and administrative control that had long been endemic in the Indonesian economy. Indonesia adopted a series of measures that had the effect of significantly liberalizing trade. Tariffs were reduced across the board and the number of tariff categories was cut in March 1985. In May 1986, export oriented industries were allowed to buy imported inputs without restriction and without import duties.

Economic Reforms during 1991-1997

The reforms in mid-1980 till mid 1990s reduced tariff across the board. As a result, the effective rate of protection remained low from early 1990 sight until 2005 when the commodity boom started (Figure 1). It had also been decreasing across 2digit ISIC industrial category (Amiti and Konings [2005] and Tri Widodo [2008]).

Figure 1: Effective Rate of Protection (ERP)

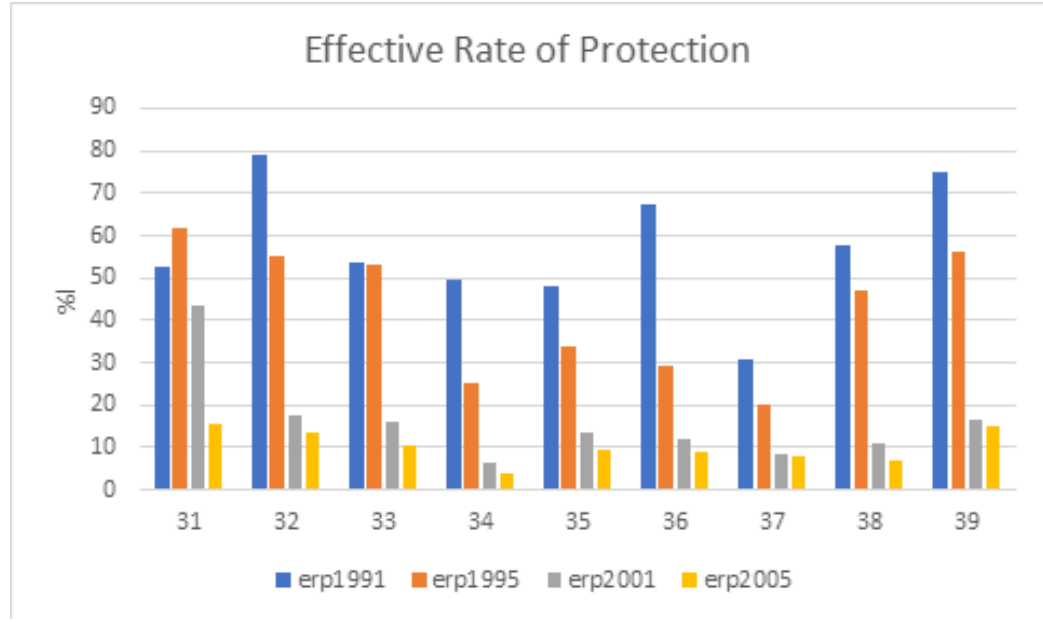

SOURCE:AMITI AND KONINGS (2005) AND TRI WIDODO (2008) 


\section{Trade Policy and Firm Behaviour}

The direction of the Indonesian trade regime started to change again in 2007 when the Susilo Bambang Yudhoyono (SBY) government launched a new law (Law no 7 in 2007) on the domestic manufacturing development. In 2007 SBY administration outlined a strategy to revive manufacturing. It is stated in Law no. 27 on long term development plan for the period 2005-2025 (RPNJP). It reaffirms manufacturing as engine of growth. to promote the country competitiveness, the intention is to improve efficiency, to modernize and to increase value added in the modern sector including mining in order not to be trapped in low value added global value chain.

The Jokowi (JKW) administration's blue print on manufacturing development is included in the campaign platform NAWACITA. In essence, manufacturing is to be revived as a source of growth. A modern concept of value chain is introduced. It is no longer only about intersectoral linkages between agriculture and manufacturing; between manufacturing and services. In short it is no longer solely about upstream manufacturing. The use of industrial policy is mentioned but there is nothing specific about instruments and targeting mechanism to achieve the goals.

Since the SBY government the trade policy has gradually moved to the direction of more protectionist stance. The reason is complex but it started by the intention to protect the Indonesia external position from the deterioration of exports in the aftermath of commodity boom. The change of the policy is indicated by the use of non-tariff measures (NTM) instead of tariff ones to curtail imports (Figure 2). This policy continues to be pursued under the JKW presidency in 2014-2015 for the same reason to protect the balance of trade from deficit. Export taxes are used to keep goods from being exported that is to stabilize the domestic market. Local content requirements are the measures intended to develop the domestic intermediate good industry. The problem is that like any intervention in the past it is difficult to find good instrument.

One instrument of NTM that is used to promote the development of domestic industry is local content requirement. It may not as proliferate as in India but still it is significant number about 15 measures in 2015 which is higher than China (Table 1). It was stated in Law Number 27, 2007 (under the SBY administration) in a rather disguised message of protectionism blanketed by the modern jargon 
of value chain. It was a value chain development through product reprocessing, diversification, structural deepening and vertical integration. Local content requirement is thought to prevent firms to acquire essential imported inputs to compete in the international market joining the global value chain.

Figure 2: Incremental in non-tariff measures 2002-2015

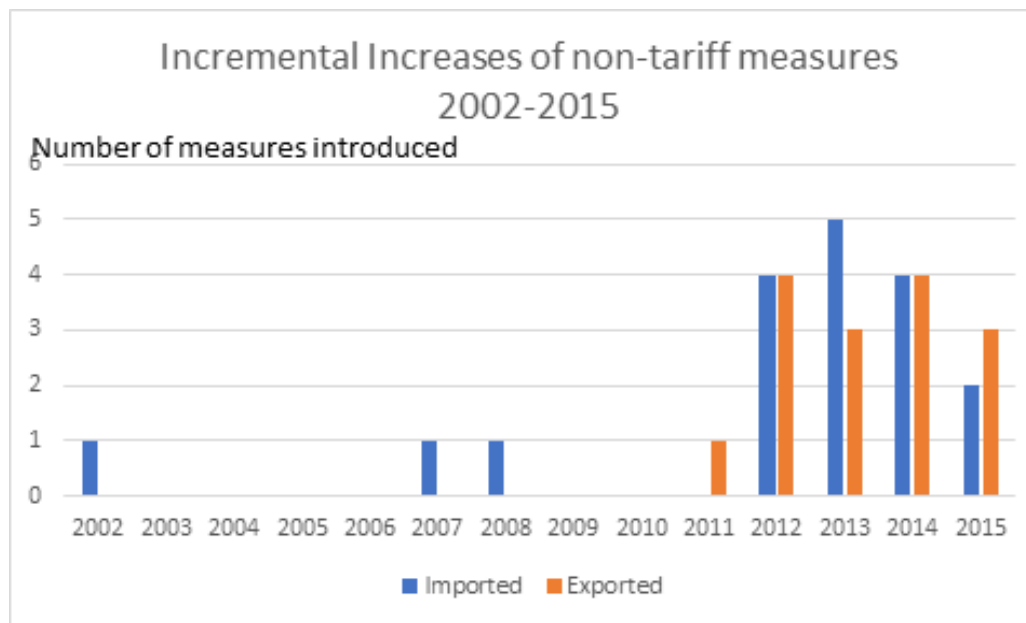

SOURCES: S.V. MARKS, 2007, TABLE I.

Table 1: Non-Tariff Measures

\begin{tabular}{|c|c|c|c|c|c|}
\hline & $\begin{array}{l}\text { INDO- } \\
\text { NESIA }\end{array}$ & CHINA & $\begin{array}{l}\text { MALAY- } \\
\text { SIA }\end{array}$ & $\begin{array}{l}\text { THAI- } \\
\text { LAND }\end{array}$ & INDIA \\
\hline Bail out/ state aid measure & 6 & 6 & I & $\mathrm{I}$ & 19 \\
\hline Competitive devaluation & 0 & 0 & 0 & 0 & 0 \\
\hline Consumption subsidy & 0 & I & 0 & 0 & 0 \\
\hline Export subsidy & 3 & 11 & 2 & I & 25 \\
\hline Export taxes or restriction & 18 & 10 & I & 2 & 24 \\
\hline Import ban & 6 & 3 & I & 0 & 6 \\
\hline Import subsidy & 0 & 0 & I & I & 2 \\
\hline Intellectual property protection & 0 & 2 & 0 & 0 & 0 \\
\hline Investment measure & 13 & 17 & 4 & 3 & 12 \\
\hline Local content requirement & 15 & 9 & 4 & 0 & 107 \\
\hline Migration measure & 2 & 1 & 2 & $\mathrm{I}$ & 2 \\
\hline Other non-tariff barriers & 25 & 9 & 3 & $\mathrm{I}$ & 12 \\
\hline Other service sector measure & 4 & 3 & 0 & 0 & I \\
\hline Public procurement & 9 & 7 & 0 & 0 & 13 \\
\hline Quota (including tariff rate quota) & 5 & 7 & 0 & 0 & 2 \\
\hline Sanitary and phytosantiary measure & 4 & 0 & 0 & 0 & 0 \\
\hline State trading enterprise & 0 & 0 & 0 & 0 & 0 \\
\hline
\end{tabular}




\begin{tabular}{|c|c|c|c|c|c|}
\hline & $\begin{array}{l}\text { INDO- } \\
\text { NESIA }\end{array}$ & CHINA & $\begin{array}{l}\text { MALAY- } \\
\text { SIA }\end{array}$ & $\begin{array}{l}\text { THAI- } \\
\text { LAND }\end{array}$ & INDIA \\
\hline State controlled company & 2 & $\mathrm{I}$ & 0 & 0 & $\mathrm{I}$ \\
\hline Sub national government measures & 0 & 2 & 0 & 0 & I \\
\hline Tariff measures & 12 & 15 & 3 & $\mathrm{I}$ & 37 \\
\hline Technical barrier to trade & 3 & $\mathrm{I}$ & 0 & 0 & 0 \\
\hline Trade defence measure & 17 & 45 & 7 & 14 & 135 \\
\hline Trade finance & $\mathrm{I}$ & $\mathrm{I}$ & 2 & 0 & 95 \\
\hline Total & 115 & $13 \mid$ & 18 & 22 & 356 \\
\hline
\end{tabular}

SOURCE: GTAACCESSED 2016

\section{Grease money}

The NTM however must be implemented by lower level bureaucrats who are not necessarily immune to grease money. As a reprieve for manufacturing firms especially those with higher need of imported input is that that the measures may have not been binding. Firms can still import input from abroad presumably by paying grease money to lower level bureaucrats. The grease money data are obtained from the expense recorded as "gift" or contribution in the annual manufacturing surveys. Manufacturing exporters tend to import proportionally higher inputs relative to non-exporters (Figure 3). They also pay higher grease money especially after 2006 reflecting the need to get around various NTM including local content scheme that have been put in place to stem import (Figure 4). But the amounts of grease money appear to be relatively small that is less than one percent of the total costs which can absorbed by profits or passed on to consumers.

Figure 3: Imported inputs as a percentage of total inputs

\section{Imported inputs as a percentage of total inputs}

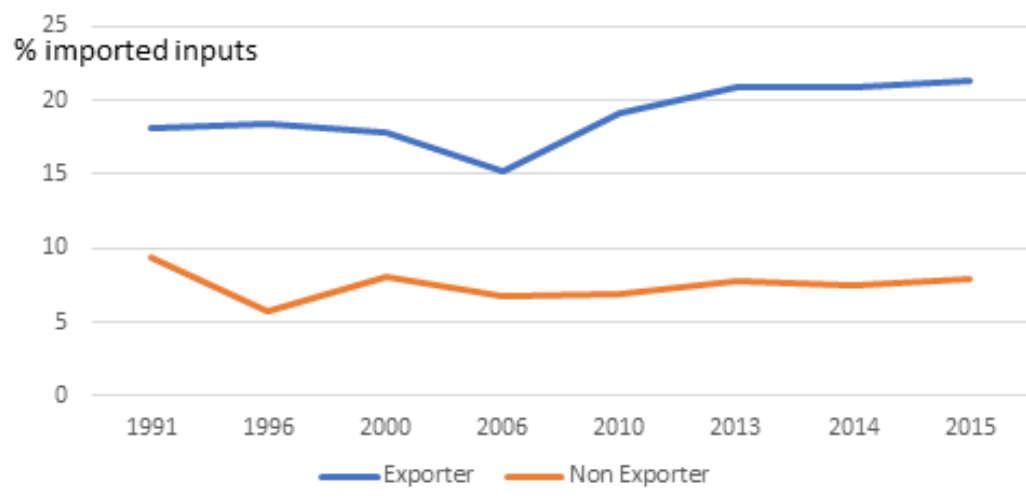

SOURCES: CALCULATED FROMTHE ANNUAL MANUFACTURING SURVEY, CENTRE OF BUREAU OF STATISTIC 
Figure 4: Grease money as a percentage of total costs

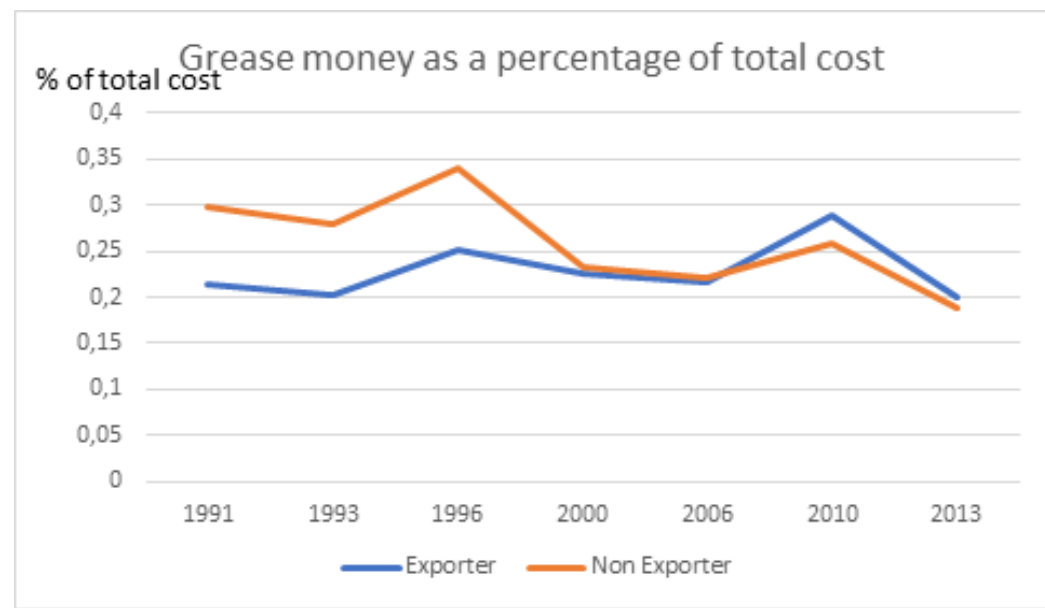

SOURCES: CALCULATED FROMTHE ANNUAL MANUFACTURING SURVEY, CENTRE OF BUREAU OF STATISTIC

Figure 5: Firm level percentage of exported output

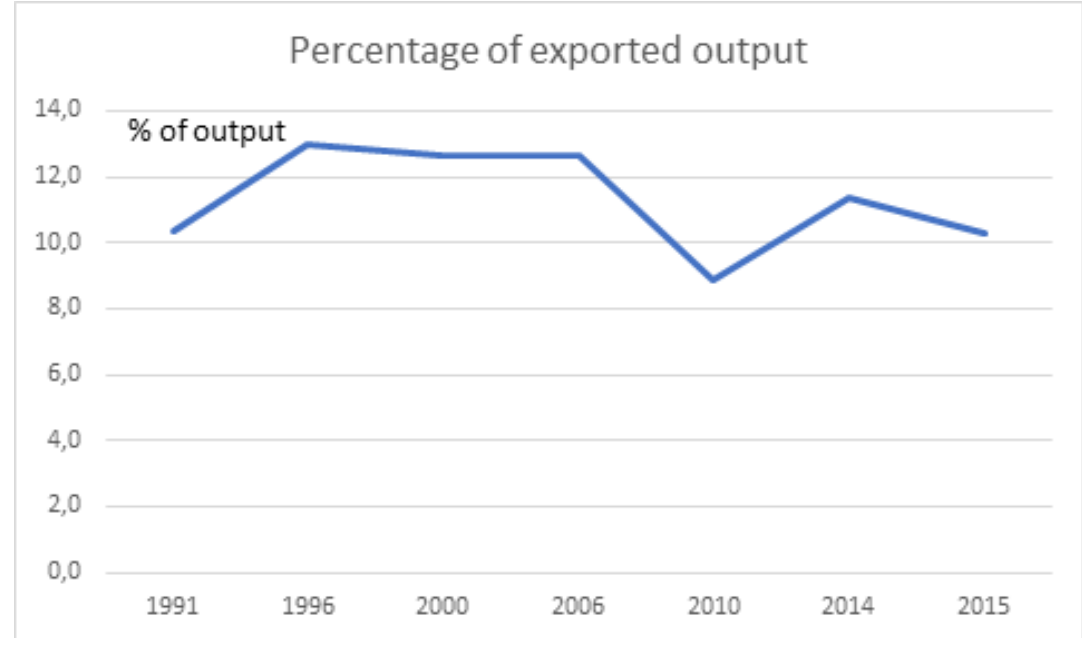

SOURCES: CALCULATED FROMTHE ANNUAL MANUFACTURING SURVEY, CENTRE OF BUREAU OF STATISTIC

To begin with, the overall export orientation of manufacturing is already low. At its peak it reached 14 percent of output and it took place before AFC. The manufacturing export orientation after AFC was lower than before AFC. The general impact of the increase in NRP and ERP on manufacturing was to reduce the incentive between exporting versus to sell domestically. Figure 5 suggests that the export 
orientation declined after 2006. Part of it might be the result of the Dutch Disease produced by the commodity boom. The second decline started in 2014. It might be attributed to the increase of NTM from 2012 onward so both the SBY and the JKW administrations shared this phenomenon. The decline is slight suggesting that a firm particularly those with significant ratio of exported output, may counteract with paying grease money to getting around the complicated NTM. The data however is not long enough to judge whether this is solely the result of the policy under the JKW administration. Here is the dilemma between protecting the trade balance and export activity. Had the import restriction been more severe, the impact of NTM on export orientation would have been more severe.

\section{Lobbying}

Lobbying is not the same as paying grease money but many elements of the former are often cannot be distinguished from bribing particularly if it contains some form of gratification for bureaucrats like dinner invitation for example. Representation expenses in the annual manufacturing surveys can be included in this category. Exporters tend to use lobbying compared to non-exporters. Since exporters are also more likely FDI firms then this subtle form of grease moneys is more preferred than blatant bribing (Figure 5). The use of lobbying declines after 2013 when the government imposed more NTM. One intriguing question is whether lobbying is complementary or substitute for bribing.

Figure 6 suggests that at least for exporters and for some periods grease money and lobbying are substitutes. Before the start of AFC, for example in 1996 when tariff and non-tariff measures were on the downward trend but they were still relatively high. Grease money are the preferred tools to smooth business transaction. Afterward due to the broad based economic reform that had been launched since the year of 1986, tariff started to come down. Grease money in terms of the percentage to total costs follow suit. The use of lobbying rose in 2006 it may reflect the very early start of the increasing use of NTM by the SBY government. The effectiveness of doing only lobbying seems to be diminished when the SBY government applying more and more NTM to the economy to stem the deficit in current account. The use of grease money has been on the increase again after 2013. Unfortunately, the firm-level annual manufacturing surveys are not 
available yet beyond 2016 so the distinction between the SBY versus the JKW administration remains unobserved.

Figure 5: Lobbying Cost

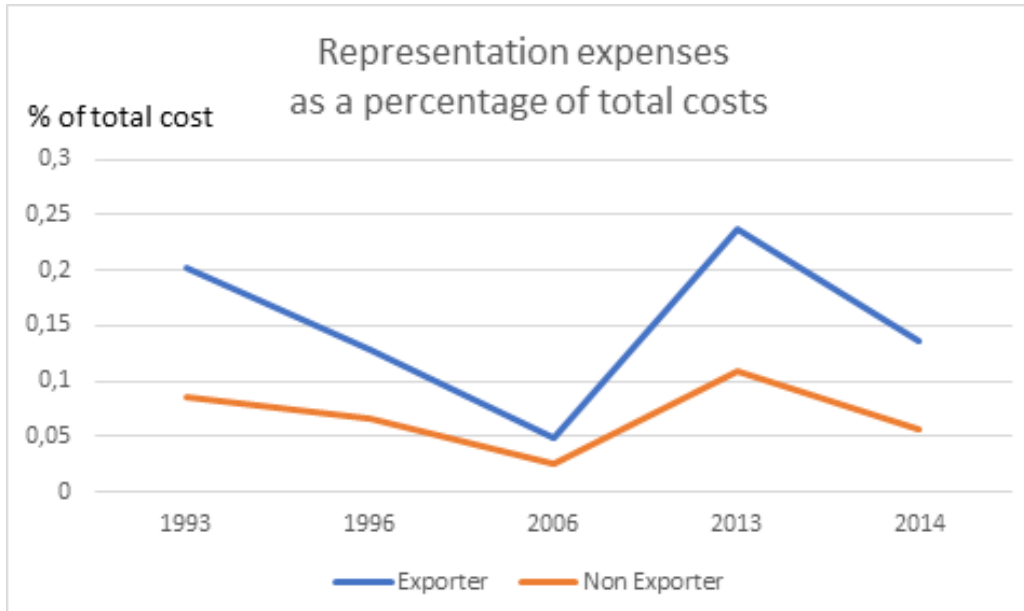

SOURCES: CALCULATED FROMTHE ANNUAL MANUFACTURING SURVEY, CENTRE OF BUREAU OF STATISTIC

Figure 6: Exporters: Grease money versus Lobbying

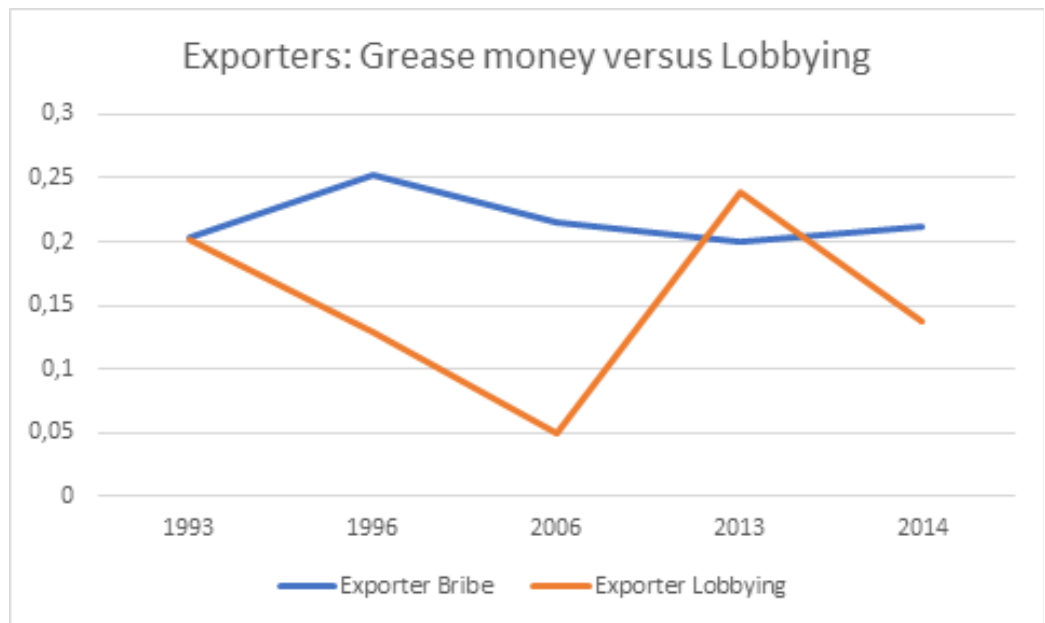

SOURCES: CALCULATED FROMTHE ANNUAL MANUFACTURING SURVEY, CENTRE OF BUREAU OF STATISTIC

\section{Firm Size}

Size is important for a firm since it captures scale economics thus the ability to absorb costs as well as political connection. Firms in 
Figure 7: Grease money by Size

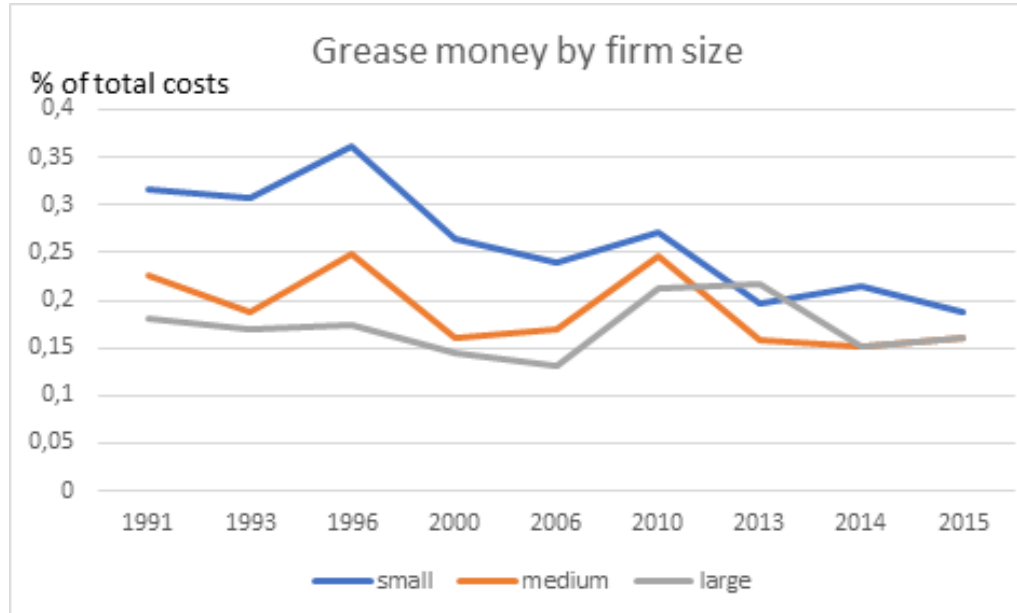

SOURCES: CALCULATED FROMTHE ANNUAL MANUFACTURING SURVEY, CENTRE OF BUREAU OF STATISTIC

Figure 8: Percentage of exported output

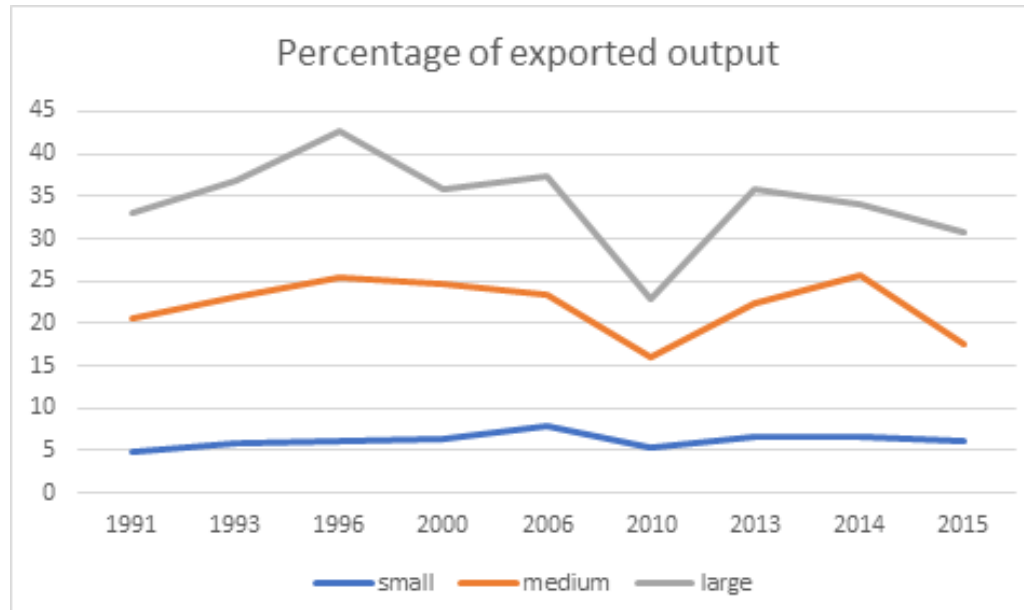

SOURCES: CALCULATED FROMTHE ANNUAL MANUFACTURING SURVEY, CENTRE OF BUREAU OF STATISTIC

the annual manufacturing surveys are divided into three different categories; small, medium and large. If the number of workers is no more than 100 then a firm is classified as small. If it is more than 100 to 500 workers then it is categorized as medium. Finally, if it is larger than 500 it will be recorded as large. The small category seems to bear disproportionately large grease money burden compared to medium and large ones. The larger grease money however does not 
mean that it has higher export orientation (Figure 7). Small firms pay disproportionately higher percentage grease money because it easier for lower level bureaucrats to prey on them. One reason is that they may have not political connection or do not have resources to ward-off corrupt bureaucrats. This is irrespective whether they are exporter or not (Figure 8). The percentage of exported output of small firms is the lowest. Therefore, in order to get estimate the relationship between the need to get imported inputs and grease moneys one must control the impact of firm size on grease money.

\section{Controlling for size}

In order to control for firm size, we estimate the following model

$$
\mathrm{GM}=\alpha+\mathrm{O}+\alpha+1 \mathrm{IMP}+\alpha+3 \mathrm{~S}+\mathrm{DEX}+\alpha+5 \mathrm{DFDI}+\varepsilon(1)
$$

Where GM is grease money as the percentage of the total costs, IMP is the percentage of imported inputs the total inputs, $\mathrm{S}$ refers to the firm size represented by three size dummies, small, medium and large where the large category serves as the base. DEX is the dummy variable for exporters, having the value of one for exporters and zero otherwise. DFDI is the dummy variable for foreign direct investment (FDI) firms with the value of one for FDI and zero otherwise. The estimation results are presented in the table 2.

\section{B. RESULTS}

\section{Grease money}

The results confirm that small firms pay higher grease money compared to medium and large ones as the coefficients are larger and highly significant in the two estimation periods (1991-2000 and 1991-2015). The burden is however smaller in the 2006-2015 periods though the government have made the trade regime tighter with respect to imports,

The good news is that the coefficients of imported inputs are all negative and significant suggesting that grease money do not prevent firms to import essential inputs from abroad. This is particularly important for exporters which surprisingly pay grease moneys not higher than their non-exporter counterparts. But small and medium exporters definitely pay higher grease money relative to larger ones 
especially in the 2006-2015 periods. This period coincides with the imposition of higher number of non-tariff measures (NTM) as the country trade policy turned into more protectionist stance.

FDI firms irrespective of their size evidently pay higher grease money compared to their non-FDI counterparts. The burdens appear higher in the 2006-2015 as the coefficient of the interactive year and FDI dummies is positive and highly significant.

Non-metallic seems to bear the highest grease money as its coefficient is positive and highly significant. Other industries appear to be in decreasing order in terms of grease money burdens as the coefficients of the industry dummies are either negative and significant or insignificant altogether. All industries where manufacturing exports are concentrated like food, textiles and machinery have all their industry dummy coefficients negative and significant.

Table 2: Determinants of grease money

\begin{tabular}{|c|c|c|c|}
\hline & $1991-2000$ & $2006-2015$ & $199 \mid-2015$ \\
\hline$\%$ of imported inputs & $-0.000 * *$ & $-0.00 I^{* *}$ & $-0.001 * * *$ \\
\hline Small firm & $\begin{array}{l}0.110 * * * \\
(4.047)\end{array}$ & $\begin{array}{l}0.051 \\
(1.480)\end{array}$ & $\begin{array}{l}0.159 * * * \\
(5.370)\end{array}$ \\
\hline Medium firm & $\begin{array}{l}-0.002 \\
(-0.06 \mathrm{I})\end{array}$ & $\begin{array}{l}-0.012 \\
(-0.432)\end{array}$ & $\begin{array}{l}0.062 * * * \\
(2.638)\end{array}$ \\
\hline Exporter & $\begin{array}{l}-0.039 * \\
(-1.67 I)\end{array}$ & $\begin{array}{l}-0.074 \\
(-1.319)\end{array}$ & $\begin{array}{l}-0.006 \\
(-0.325)\end{array}$ \\
\hline Small $X$ Exporter & $\begin{array}{l}-0.004 \\
(-0.112)\end{array}$ & $\begin{array}{l}0.108 * \\
(1.916)\end{array}$ & \\
\hline Medium X Exporter & $\begin{array}{l}0.048 * \\
(1.647)\end{array}$ & $\begin{array}{l}0.107 * * \\
(2.545)\end{array}$ & \\
\hline FDI & $\begin{array}{l}0.014 \\
(0.430)\end{array}$ & $\begin{array}{l}0.224 * * * \\
(2.830)\end{array}$ & $\begin{array}{l}0.042 * \\
(1.706)\end{array}$ \\
\hline Small X FDI & $\begin{array}{l}-0.054 \\
(-1.029)\end{array}$ & $\begin{array}{l}-0.076 \\
(-0.690)\end{array}$ & \\
\hline Medium X FDI & $\begin{array}{l}0.034 \\
(0.675)\end{array}$ & $\begin{array}{l}-0.069 \\
(-0.687)\end{array}$ & \\
\hline Food and beverages & $\begin{array}{l}-0.127^{* * *} \\
(-8.132)\end{array}$ & $\begin{array}{l}-0.066 * * * * \\
(-3.130)\end{array}$ & $\begin{array}{l}-0.081 * * * \\
(-4.557)\end{array}$ \\
\hline Textiles & $\begin{array}{l}-0.124 * * * \\
(-9.102)\end{array}$ & $\begin{array}{l}-0.038 * * * \\
(-5.125)\end{array}$ & $\begin{array}{l}-0.062 * * * \\
(-9.498)\end{array}$ \\
\hline Wood and wood products & $\begin{array}{l}-0.033 \\
(-0.88 I)\end{array}$ & $\begin{array}{l}-0.023 * * * \\
(-2.942)\end{array}$ & $\begin{array}{l}-0.019 \\
(-1.054)\end{array}$ \\
\hline Paper and printing & $\begin{array}{l}-0.024 \\
(-0.329)\end{array}$ & $\begin{array}{l}-0.025 \\
(-0.699)\end{array}$ & $\begin{array}{l}-0.024 \\
(-0.520)\end{array}$ \\
\hline Chemicals & $\begin{array}{l}-0.107 * * * \\
(-5.106)\end{array}$ & $\begin{array}{l}-0.037 \\
(-1.133)\end{array}$ & $\begin{array}{l}-0.055^{*} \\
(-1.943)\end{array}$ \\
\hline Non-metallic & $\begin{array}{l}0.033 \\
(0.748)\end{array}$ & $\begin{array}{l}0.072 * * * * \\
(3.591)\end{array}$ & $\begin{array}{l}0.064 * * * \\
(6.211)\end{array}$ \\
\hline Basic metals & $\begin{array}{l}-0.128^{* *} \\
(-2.398)\end{array}$ & $\begin{array}{l}-0.083 * * * \\
(-6.04 I)\end{array}$ & $\begin{array}{l}-0.096 * * * \\
(-19.437)\end{array}$ \\
\hline Machinery & $\begin{array}{l}-0.062 * * * \\
(-4.343)\end{array}$ & $\begin{array}{l}-0.044^{* *} \\
(-2.122)\end{array}$ & $\begin{array}{l}-0.047 * * * * \\
(-2.985)\end{array}$ \\
\hline
\end{tabular}




\begin{tabular}{|c|c|c|c|}
\hline & $|99|-2000$ & $2006-2015$ & $1991-2015$ \\
\hline $\begin{array}{l}\text { Small X year 2006-20I5 } \\
\text { Medium X year 2006-20I5 } \\
\text { Exporter X year 2006-20I5 } \\
\text { FDI X year 2006-20I5 } \\
\text { Constant } \\
\text { Number of observations } \\
\text { Adjusted R2 }\end{array}$ & $\begin{array}{l}0.295 * * * \\
(12.074) \\
55,485 \\
0.011\end{array}$ & $\begin{array}{l}0.200 * * * \\
(6.050) \\
131,439 \\
0.003\end{array}$ & $\begin{array}{l}-0.100^{* * *} \\
(-7.019) \\
-0.063^{* * *} \\
(-4.399) \\
0.014 \\
(0.740) \\
0.116^{* * *} \\
(2.339) \\
0.206 * * * \\
(7.355) \\
186,924 \\
0.005\end{array}$ \\
\hline
\end{tabular}

SOURCES: CALCULATED FROMTHE ANNUAL MANUFACTURING SURVEY, CENTRE OF BUREAU OF STATISTIC Notes:

*** significant at the I percent level

** significant at the 5 percent level

* significant at the 10 percent level Figures between parentheses are t-statistics

\section{Lobbying or Representation Costs}

The use of lobbying is more intensive in the full sample regression (1991-2015) although the coefficient is only weakly significant (Table 3). Small firms are less likely to lobby for leniency as their resources are more limited. Exporters tend to spend more money to lobby bureaucrats compared to their non-exporter counterparts. Similarly, FDI firms are also more active in lobbying than non FDI ones. Almost all industries resort to lobbying when come to difficulty to get imported inputs. Food and textiles are the only two exceptions as their coefficients for industry dummies are mostly negative and significant for all samples. Interestingly, the use of lobbying is presumably decreasing when the government imposing non-tariff measures to curb import in the 2006-2015 period. Presumably, lobbying is deemed less effective when trade regime become tighter and firms resort to use grease money blatantly. Therefore, unlike suggested by the analysis before, there is some substitution between lobbying (representation) and grease money (gift or contribution) at least in the later period of the samples.

Table 3: Determinants of lobbying costs

\begin{tabular}{l|l|l|l}
\hline & \multicolumn{1}{|c|}{$1993-1996$} & \multicolumn{1}{|c}{$\mathbf{2 0 0 6 - 2 0 I 4}$} & \multicolumn{1}{|c}{$\mid$ 1993-20I4 } \\
\hline \% of imported input & 0.000 & 0.001 & $0.00 I^{*}$ \\
Small firm & $(0.129)$ & $(I .317)$ & $(I .655)$ \\
& $-0.055^{* *}$ & -0.039 & $-0.046 * *$ \\
Medium firm & $(-2.106)$ & $(-1.457)$ & $(-2.080)$ \\
& -0.001 & -0.022 & -0.016 \\
& $(-0.024)$ & $(-0.860)$ & $(-0.729)$ \\
\hline
\end{tabular}




\begin{tabular}{|c|c|c|c|}
\hline & $1993-1996$ & 2006-2014 & $1993-2014$ \\
\hline$\%$ imported input $X$ small & $0.001 *$ & -0.000 & 0.000 \\
\hline$\%$ imported input $X$ medium & $\begin{array}{l}0.001 \\
(1.007)\end{array}$ & $\begin{array}{l}-0.001 \\
(-1.334)\end{array}$ & $\begin{array}{l}-0.000 \\
(-0.573)\end{array}$ \\
\hline Exporter & $\begin{array}{l}0.048 * * * * \\
(3.021)\end{array}$ & $\begin{array}{l}0.059 * * * \\
(2.619)\end{array}$ & $\begin{array}{l}0.056 * * * \\
(3.594)\end{array}$ \\
\hline$\%$ imported input $\mathrm{X}$ exporter & $\begin{array}{l}-0.000 \\
(-0.417)\end{array}$ & $\begin{array}{l}-0.001 \\
(-1.449)\end{array}$ & $\begin{array}{l}-0.00 I \\
(-I .4 I I)\end{array}$ \\
\hline FDI & $\begin{array}{l}0.040 * \\
(1.869)\end{array}$ & $\begin{array}{l}0.065 * * * \\
(2.895)\end{array}$ & $\begin{array}{l}0.057 * * * \\
(2.756)\end{array}$ \\
\hline$\%$ imported input $X$ FDI & $\begin{array}{l}0.000 \\
(0.497)\end{array}$ & $\begin{array}{l}-0.000 \\
(-1.314)\end{array}$ & $\begin{array}{l}-0.000 \\
(-0.687)\end{array}$ \\
\hline Food and beverages & $\begin{array}{l}-0.045 * * * \\
(-7.249)\end{array}$ & $\begin{array}{l}0.034 * * * \\
(3.957)\end{array}$ & $\begin{array}{l}0.012 * \\
(1.912)\end{array}$ \\
\hline Textiles & $\begin{array}{l}-0.042 * * * \\
(-7.722)\end{array}$ & $\begin{array}{l}0.024 * * * \\
(3.265)\end{array}$ & $\begin{array}{l}0.007 \\
(1.592)\end{array}$ \\
\hline Wood and wood products & $\begin{array}{l}0.018 \\
(0.872)\end{array}$ & $\begin{array}{l}0.026 \text { *** } \\
(4.118)\end{array}$ & $\begin{array}{l}0.032^{* * * *} \\
(2.763)\end{array}$ \\
\hline Paper and printing & $\begin{array}{l}0.090 \\
(1.609)\end{array}$ & $\begin{array}{l}0.149 * * \\
(2.340)\end{array}$ & $\begin{array}{l}0.133^{* *} \\
(2.155)\end{array}$ \\
\hline Chemicals & $\begin{array}{l}-0.010 \\
(-0.358)\end{array}$ & $\begin{array}{l}0.064 * * * \\
(3.610)\end{array}$ & $\begin{array}{l}0.044^{* *} \\
(2.105)\end{array}$ \\
\hline Non-metallic & $\begin{array}{l}-0.021^{*} \\
(-1.834)\end{array}$ & $\begin{array}{l}0.039 * * \\
(2.282)\end{array}$ & $\begin{array}{l}0.025^{*} \\
(1.777)\end{array}$ \\
\hline Basic metal & $\begin{array}{l}-0.059 * * * \\
(-12.8 \mid 8)\end{array}$ & $\begin{array}{l}0.197 \text { *** } \\
(2.980)\end{array}$ & $\begin{array}{l}0.136 * * \\
(2.543)\end{array}$ \\
\hline Machinery & $\begin{array}{l}0.038 \\
(1.298)\end{array}$ & $\begin{array}{l}0.169 * \\
(1.860)\end{array}$ & $\begin{array}{l}0.130 * * \\
(1.964)\end{array}$ \\
\hline Imported input X 2006-20I5 & & & $\begin{array}{l}-0.000^{*} \\
(-1.709)\end{array}$ \\
\hline Constant & $\begin{array}{l}0.124 * * * \\
(4.499)\end{array}$ & $\begin{array}{l}0.032 \\
(1.179)\end{array}$ & $\begin{array}{l}0.059 * * * \\
(2.606)\end{array}$ \\
\hline Number of observations & 39,573 & 79,391 & 118,964 \\
\hline Adjusted R2 & 0.010 & 0.005 & 0.005 \\
\hline
\end{tabular}

SOURCES: CALCULATED FROMTHE ANNUAL MANUFACTURING SURVEY, CENTRE OF BUREAU OF STATISTIC

Notes:

*** significant at the I percent level

** significant at the 5 percent level

* significant at the 10 percent level

Figures between parentheses are t-statistics

\section{Firms survivability in exporting}

Firms may suspend export activity temporarily or even permanently if obtaining imported inputs becomes too costly or too difficult. For this, we estimate the probability of firms to export using the Probit procedure (Table 4).

The availability of imported inputs is important for a firm to survive in the export market. So, import restriction would harm exportoriented firms, which poses a dilemma for the government as well as business ethic as firms may resort to grease money to ease the import restriction. The coefficient is positive and significant at the 1 percent level in the 2006-2015 and the full samples. Small and medium size 
firms are less likely to export compared to large ones. FDI is very likely to export as the coefficient of the dummy is strongly significant and positive at the 1 percent level. Only wood and wood products show positive coefficient suggesting that the Indonesian manufacturing is relatively not too export oriented. There is no improvement overtime as none of the interactive term between the year 2006-2015 and various dummies is positive and strongly significant. This may be the result of the in the increase of the non-tariff measures (NTM) in the 2006-2015 period.

Table 4: Determinants of the firm probability to export

\begin{tabular}{|c|c|c|c|}
\hline & $1991-2000$ & $2006-2015$ & $1991-2015$ \\
\hline$\%$ imported input & $\begin{array}{l}0.003 \\
(1.609)\end{array}$ & \begin{tabular}{|l|}
$0.005 * * *$ \\
$(2.986)$
\end{tabular} & \begin{tabular}{|l|}
$0.004 * * *$ \\
$(3.833)$
\end{tabular} \\
\hline Small size firm & $\begin{array}{l}-1.374 * * * \\
(-14.25)\end{array}$ & $\begin{array}{l}-1.070 \text { *** } \\
(-8.586)\end{array}$ & $\begin{array}{l}-1.286 \text { *** } \\
(-21.13)\end{array}$ \\
\hline Small X\% imported input & $\begin{array}{l}0.002 \\
(1.384)\end{array}$ & $\begin{array}{l}-0.001 \\
(-0.479)\end{array}$ & \\
\hline Medium size firm & $\begin{array}{l}-0.446 * * * \\
(-3.496)\end{array}$ & $\begin{array}{l}-0.344 * * * \\
(-4.79 I)\end{array}$ & $\begin{array}{l}-0.370 * * * \\
(-3.822)\end{array}$ \\
\hline Medium $X \%$ imported input & $\begin{array}{l}-0.001 \\
(-0.230)\end{array}$ & $\begin{array}{l}-0.002 \\
(-1.517)\end{array}$ & \\
\hline FDI firms & $\begin{array}{l}0.725^{* * * * *} \\
\text { (II.904) }\end{array}$ & $\begin{array}{l}0.885 * * * \\
(17.697)\end{array}$ & $\begin{array}{l}0.527 \text { *** } \\
(6.577)\end{array}$ \\
\hline FDI $X \%$ imported input & $\begin{array}{l}0.000 \\
(0.279)\end{array}$ & $\begin{array}{l}0.000 \\
(0.489)\end{array}$ & \\
\hline Food and beverages & $\begin{array}{l}-0.679 * * * \\
(-7.009)\end{array}$ & $\begin{array}{l}-0.548 * * * \\
(-3.765)\end{array}$ & $\begin{array}{l}-0.588 * * * \\
(-4.492)\end{array}$ \\
\hline Textiles & $\begin{array}{l}-0.412^{* *} \\
(-2.205)\end{array}$ & $\begin{array}{l}-0.466 \text { *** } \\
(-10.24)\end{array}$ & $\begin{array}{l}-0.433 \text { *** } \\
(-4.596)\end{array}$ \\
\hline Wood and wood products & $\begin{array}{l}0.37 \mid * * * * \\
(5.558)\end{array}$ & $\begin{array}{l}0.578 \text { *** } \\
(5.443)\end{array}$ & $\begin{array}{l}0.516 \text { **** } \\
(5.287)\end{array}$ \\
\hline Paper and printing & $\begin{array}{l}-1.156 * * * \\
(-6.724)\end{array}$ & $\begin{array}{l}-0.797 \text { *** } \\
(-4.612)\end{array}$ & $\begin{array}{l}-0.903 * * * \\
(-5.268)\end{array}$ \\
\hline Chemicals & $\begin{array}{l}-0.620 * * * \\
(-3.591)\end{array}$ & $\begin{array}{l}-0.465 * * * \\
(-2.725)\end{array}$ & $\begin{array}{l}-0.528 * * * \\
(-3.126)\end{array}$ \\
\hline Non-Metallic & $\begin{array}{l}-0.936 * * * \\
(-5.027)\end{array}$ & $\begin{array}{l}-0.65 \mathrm{I} \text { **** } \\
(-3.18 \mathrm{I})\end{array}$ & $\begin{array}{l}-0.738 \text { *** } \\
(-3.757)\end{array}$ \\
\hline Basic Metal & $\begin{array}{l}-0.559 * * * \\
(-3.410)\end{array}$ & $\begin{array}{l}-0.570 * * \\
(-2.112)\end{array}$ & $\begin{array}{l}-0.608 * * \\
(-2.513)\end{array}$ \\
\hline Machinery & $\begin{array}{l}-0.887 * * * \\
(-9.714)\end{array}$ & $\begin{array}{l}-0.646 * * * \\
(-12.33)\end{array}$ & $\begin{array}{l}-0.725 * * * \\
(-13.15)\end{array}$ \\
\hline$\%$ imported input $\times 2006-15$ & & & $\begin{array}{l}-0.000 \\
(-0.532)\end{array}$ \\
\hline Small X FDI & & & $\begin{array}{l}0.613^{* * *} \\
(7.1 \mid 2)\end{array}$ \\
\hline Medium X FDI & & & $\begin{array}{l}0.170 * * \\
(2.275)\end{array}$ \\
\hline Small X 2006-15 & & & $\begin{array}{l}0.022 \\
(0.298)\end{array}$ \\
\hline Medium X 2006-I5 & & & $\begin{array}{l}-0.126^{*} \\
(-1.876)\end{array}$ \\
\hline $\mathrm{FDI} \times 2006-15$ & & & $\begin{array}{l}0.080 \\
(1.100)\end{array}$ \\
\hline
\end{tabular}




\begin{tabular}{l|l|l|l}
\hline & \multicolumn{1}{|c|}{ 199I-2000 } & \multicolumn{1}{|c}{ 2006-20I5 } & \multicolumn{1}{|c}{ I99I-20I5 } \\
\hline Constant & $0.370 * * *$ & -0.025 & $0.185^{* *}$ \\
& $(3.796)$ & $(-0.255)$ & $(2.283)$ \\
Number of observations & 55,528 & 131,439 & 186,967 \\
Adjusted R2 & 0.242 & 0.219 & 0.227 \\
\hline
\end{tabular}

SOURCES: CALCULATED FROMTHE ANNUAL MANUFACTURING SURVEY, CENTRE OF BUREAU OF STATISTIC Notes:

*** significant at the I percent level

** significant at the 5 percent level

* significant at the 10 percent level

Figures between parentheses are t-statistics

\section{CONCLUSION}

For a private firm the primary concern of stakeholders from management, employees and shareholders is sustainability. Not so much about ethics, particularly if survival is at stake. Business environment however is not always friendly. Uncertainty could come from government regulations. Many regulations are created to correct for negative externalities from private firm operation. But some regulations have their own twist. One is the customization of regulation in order to create bureaucratic delay so private firms having to do business would have no choice but to pay grease money, Various governments have forbidden private firms to pay grease moneys to host country's bureaucrats. Facing the possibility of business stoppage, many firms would have no choice but to pay grease money to speed up the process.

One example of regulation that may have adverse impact on manufacturing is import restriction or import licensing on vital imported inputs. In order to produce high quality product firms often have import critical inputs simply because the domestic industry is unable to meet the quality or simply it does not exist. Particularly so is an export-oriented firm that has to compete in the global market.

Interestingly, import bans, import restrictions and other types of quantitative restrictions may not be binding. The execution of prohibitive regulations is mainly in the hand of lower level bureaucrats. With weak supervision from the upper echelon, private firms with their survivability at stake may have to forego "ethics" by bribing lower level bureaucrats in order to obtain vital inputs.

The use of tariff as an instrument to limit imports have fallen dramatically due to the role of World Trade Organization (WTO), multilateral and bilateral agreements. But in adherence to the WTO 
regulations, it has been replaced by more subtle form of non-tariff measures (NTM) ranging from health to environmental concerns. In the Indonesian case, the deterioration of the current account balance in the post-commodity boom from 2012 onward had instituted many non-tariff barriers. The usual argument is to protect the domestic from unfair external competition.

But the end result may be just the opposite of what is originally intended. Using the annual survey of Indonesia manufacturing we examine the behaviour of manufacturing in the post-commodity boom era after 2012 when the country is becoming more protectionist. The initial hypothesis suggests that exporting firms use imported inputs proportionally higher than non-exporters. As a result, when the government restricted import in the post commodity boom era, the proportion of grease money and representation expense is higher than their non-exporting counterparts. This behaviour is also observed when instead, FDI versus non FDI firms are compared. Overall there is no increase on the firm export orientation

\section{REFEREN CES}

Amiti, M., and J. Konings, 2007, “Trade Liberalization, Intermediate Inputs and Productivity: Evidence from Indonesia, American Economic Review, vol. (97), p. 1611-1638

Bardhan, P., 1997, "Corruption and Development: A Review of issues," Journal of Economic Literature, vol. 35 (September), p. 1320-1346

Bliss, C.J.E, and R. Di Tella, 1997, "Does Competition Kill Corruption," Journal of Political Economy, vol 105(5), p. 1001-1023

MacIntyre, Andrew, "Investment, Property Rights, and Corruption in Indonesia," in Campos, J.E.(ed), 2001, Corruption: The Boom and Bust of East Asia, Ateneo de Manila University Press.

Rose-Ackerman, S., 2008, "Corruption and Government," International Peacekeeping, vol. 3., p. 328-343.

Shleifer, A. and R.W. Vishny, 1993, “Corruption,” Quarterly Journal of Economics, vol. 108, p. 599-617.

Shliefer, A. and R. A. Vishny, 1997, "A Survey of Corporate Governance,” Journal of Finance, vol. 52(2), p. 737-783.

Widodo, T., 2008, "Structure of Protection in Indonesian Manufacturing Sector,” ASEAN Economic Bulletin, vol. 25(2), p. $161-78$ 